\title{
Occurrence of azooxanthellate scleractinian corals off Goa, mid-west coast of India
}

\author{
Lazarus Singarayan and Chandran Rethnaraj
}

\begin{abstract}
Background: West coast of India is characterized by the presence of rich rocky out-crops with a diversity of poorly illuminated vertical rocky walls, crevices, caves, tunnels and overhangs. Though these are the typical environment for azooxanthellate scleratinian corals, there is no report available on these corals from this region.

Methods: In situ observations including photography were made by SCUBA diving Collected specimens were soaked in fresh water and then in sodium hypochlorite solution for cleaning. Finer details of coralla were photographed using a stereoscopic microscope.

Result: The present account reported three species of azooxanthellate corals namely Balanophyllia cumingii Milne Edwards \& Haime, 1848, Dentrophyllia indica Pillai, 1969 and Paracyathus profundus Duncan, 1889 for the first time from the rocky out-crops off Goa, mid-west coast of India and illustrated with in situ morphological characters of the species recorded.

Conclusion: Despite their rich biodiversity, the seas and the deep shelf regions adjacent to India have had few surveys and limited reports (34 species) only are available on the occurrence of azooxanthellate corals. Detailed further studies along the coast would unveil the presence of more number of species.
\end{abstract}

Keywords: Azooxanthellate, Coral, Balanophyllia, Dentrophyllia, Paracyanthus, Mid-west coast, India

Abbreviation: SCUBA, Self contained underwater breathing apparatus

\section{Background}

Azooxanthellate corals are found in dark habitats (sciophilous), especially within caverns (cavernicolous) (Dinesen, 1982, 1983). Since they do not live symbiotically with dinoflagellate algae, their distribution is not limited to the euphotic zone alone, but are ubiquitous, known from the Tropical seas to Polar seas and from the intertidal zone to over $6328 \mathrm{~m}$ depth (Cairns \& Stanley, 1982). There are 227 species of azooxanthellate scleractinian corals belonging to 71 genera reported from Indian Ocean region (Cairns \& Kitahara, 2012; Cairns, 2004). One-third of the azooxanthellate species occur off Australia, making it one of the richest regions in the world for this type of corals. A total of 34 species from 18 genera and 4 families are reported so far from Indian waters including Gulf of Kutch, Gulf of Mannar, Andaman and Nicobar Islands and Lakshadweep Islands (Table 1). Some

\footnotetext{
* Correspondence: softcoralchandran@gmail.com

Institute for Environmental Research and Social Education, 150, II Cross

Street, Nesamony Nagar, Nagercoil, Tamilnadu 629001, India

sporadic reports of azooxanthellate corals only are available from the west coast of India (Alcock, 1893; 1898). The west coast of India is characterized by rocky out crops with poorly illuminated environments which harbour a diversity of ahermatypic corals. Species described from Indian waters so far were collected from trawl net landings which are in the form of bleached and broken pieces. None of the authors mentioned above described their live morphology and habitat type. This present account, illustrates the in situ morphology of three species of azooxanthellate corals reported for the first time from the rocky outcrops off Goa, mid-west coast of India.

\section{Methods}

In situ observations including photography were made by SCUBA diving and azooxantheallate coral samples were collected from the depth ranging between $8 \mathrm{~m}$ and $11 \mathrm{~m}$ from the crevices and shaded regions of rocky outcrops

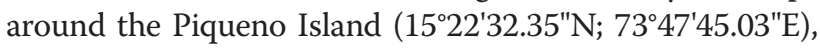


Table 1 Species of azooxanthellate corals recorded from Indian waters

\begin{tabular}{|c|c|c|c|c|c|c|c|c|c|}
\hline S.No. & Family & Genus & Species & Lakshadweep & $\begin{array}{l}\text { Gulf of } \\
\text { Kuthch }\end{array}$ & $\begin{array}{l}\text { Gulf of } \\
\text { Mannar }\end{array}$ & $\begin{array}{l}\text { Andaman \& } \\
\text { Nicobar Islands }\end{array}$ & $\begin{array}{l}\text { South West } \\
\text { coast }\end{array}$ & $\begin{array}{l}\text { Mid-west } \\
\text { coast (Goa) }\end{array}$ \\
\hline 1 & & Caryophyllia & C. clavus & $d$ & & & $d$ & & \\
\hline 2 & & & C. arcuata & e & & & $d$ & c & \\
\hline 3 & & & C. acanthocyathus & & & & $d$ & & \\
\hline 4 & & Deltocyathus & D. andamanicus & & & & e & & \\
\hline 5 & & Paracyathus & P. indicus & & & & e & & \\
\hline 6 & & & P. profundus & & & b & & c & $f$ \\
\hline 7 & & & P. stokesii & & e & $d$ & $d$ & c & \\
\hline 8 & Caryophyllidae & Polycyanthus & P. verrilli & & e & a & e & & \\
\hline 9 & & & P. andamanensis & & & & e & & \\
\hline 10 & & Heterocyanthus & H. aequicostatus & & & $d$ & $d$ & $c \& d$ & \\
\hline 11 & & Solonosmilia & S. variabilis & & & & & c & \\
\hline 12 & & Stephanocyathus & S. nobilis & e & & & & & \\
\hline 13 & Flabellidae & Flabellum & F. pavonium & e & & & & & \\
\hline 14 & & & F. stokesi & & & & & c & \\
\hline 15 & & Placotrocus & P.levis & & & e & e & & \\
\hline 16 & Rhizangiidae & Culicia & C. rubeola & & & e & $d$ & & \\
\hline 17 & & Cladangia & C. exusta & & & e & & & \\
\hline 18 & & Balanophyllia & B. affinis & & & e & & & \\
\hline 19 & & & B. cumingii & & & & & c & $f$ \\
\hline 20 & & & B. imperialis & & & & e & & \\
\hline 21 & Dendrophyllidae & & B. scabra & & & & e & & \\
\hline 22 & & Endopachys & E. grayi & & & & $d$ & c & \\
\hline 23 & & & E. philippinensis & & & e & & & \\
\hline 24 & & & E. amphelioides & & & & $d$ & & \\
\hline 25 & & Endopsamia & E. marenzelleri & & & & $d$ & & \\
\hline 26 & & Heteropsammia & H. cochlea & & & & & c & \\
\hline 27 & & & H. michelini & & & e & e & & \\
\hline 28 & & Tubastrea & T. aurea & & e & e & e & c & \\
\hline 29 & & & D. coarctata & & & e & & & \\
\hline 30 & & Dendrophyllia & D. cornigera & & & & & c & \\
\hline 31 & & & D. arbuscula & & & & $d$ & & \\
\hline 32 & & & D.micanthus & & & $d$ & & & \\
\hline 33 & & & D. minuscula & & e & & $d$ & c & \\
\hline \multirow[t]{2}{*}{34} & & & D. indica & & & $a \& e$ & & c & $f$ \\
\hline & & & Total & 4 & 4 & 13 & 20 & 12 & 3 \\
\hline
\end{tabular}

$\mathrm{a}=$ (as reported by Pillai, 1969); $\mathrm{b}=$ (as reported by Pillai, 1986); $\mathrm{c}=$ (as reported by Pillai and Jasmine 1995); $\mathrm{d}=$ (as reported by Venkataraman, 2006); $=$ (as reported by Venkataraman, 2007) and $f=$ (as per the present study)

Grande Island (15'21'9.44"N; $\left.73^{\circ} 46^{\prime} 44.44^{\prime \prime} \mathrm{E}\right)$ and St. George Island $\left(15^{\circ} 21^{\prime} 8.86 " N\right.$; $\left.73^{\circ} 45^{\prime} 49.15^{\prime \prime E}\right)$, off Goa, midwest coast of India (Fig. 1). Collected specimens were soaked in fresh water and then in sodium hypochlorite solution for cleaning. Finer details of coralla were photographed using a stereoscopic microscope. Specimens were identified following, Pillai (1969), Pillai and Jasmine (1995) and Cairns and Kitahara (2012).

\section{Results}

\section{SYSTEMATICS}

Order SCLERACTINIA Bourne, 1900 Suborder DENDROPHYLLIINA Vaughan \& Wells, 1943

Family DENDROPHYLLIIDAE Gray, 1847 


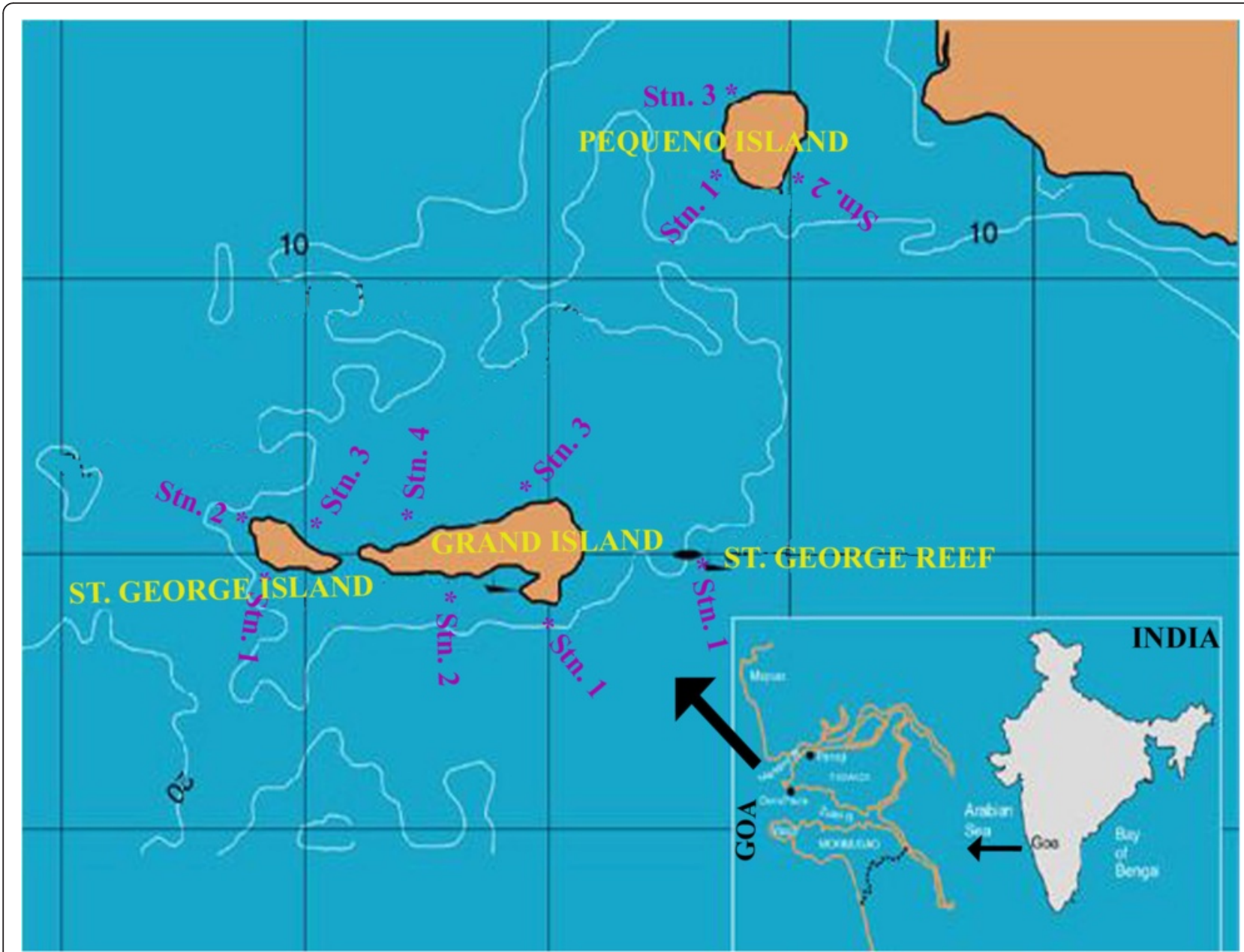

Fig. 1 Map showing the sampling stations off Goa, mid-west coast of India

Balanophyllia Wood, 1844

Balanophyllia cumingii Milne Edwards \& Haime, 1848 (Fig. 2a-d)

Balanophyllia cumingii Bourne, 1905, p.209, pl.2, Figs. 7, 7a (synonymy);

Balanophyllia cumingii Gardiner and Waugh, 1939, p. 238, pl.1, Fig. 1;

Balanophyllia cumingii Scheer and Pillai 1983, p. 168, pl.38, Fig. 8.9 (Synonymy)

\section{Diagnosis}

The corallite is funnel shaped with a narrow pedicel. Corallum is solitary, compressed, grayish white in colour when alive. Tentacles are transparent (Fig. 2a). Corallite total height is $17 \mathrm{~mm}$ and is not with a definite shape. Diameter of corallite at the top is $17 \mathrm{~mm} \times 11 \mathrm{~mm}$. Basal diameter is $14 \mathrm{~mm}$. Septa is in five cycles, primaries and secondaries subequal and projecting into calyx and slightly exert. Septa is narrow and vertically descending to meet the columella. At least three cycles reach columella. Fifth cycle units to fourth which in turn units to third. Fossa deep, $7 \mathrm{~mm}$ in larger corallite. Columella is spongy at the bottom of calicular fossa. Costae conspicuous at top of calyx with spinulations (Fig. 2b-d).

\section{Distribution}

This species has the zoogeographic distribution around Red Sea, Sri Lanka, Maldives, East Indies and Philippines (Cairns, 1994). In India, this species was reported from the Kerala coast by Pillai and Jasmine (1995). Present account confirms its distribution along the middle-west coast up to Goa.

Order SCLERACTINIA Bourne, 1900

Suborder DENDROPHYLLIINA Vaughan \& Wells, 1943

Family DENDROPHYLLIIDAE Gray, 1847

Dendrophyllia de Blainville, 1830

Dendrophyllia indica Pillai, 1969

(Fig. 3a-d) 


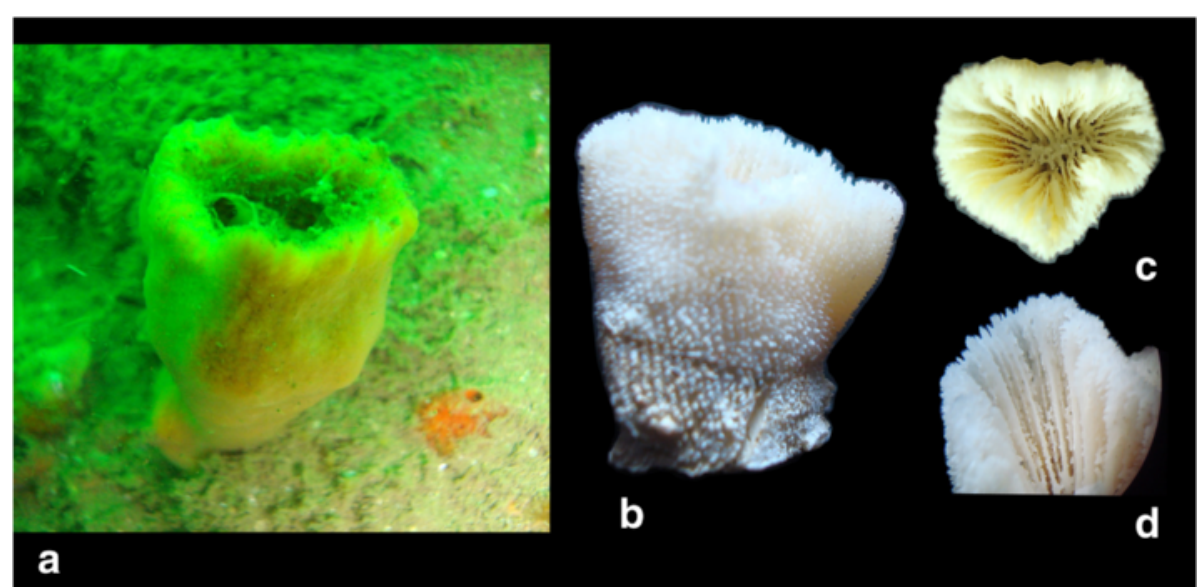

Fig. 2 Azooxanthellate scleratinian corals recorded from Goa, mid-west coast of India. a In situ specimen of Balanophyllia cumingii Milne Edwards \& Haime, 1848. b Bleached corallite of Balanophyllia cumingii. c-d Stereoscopic images of the septa of Balanophyllia cumingii

Dendrophyllia indica Pillai, 1969b, p. 407, pls. 1, 2. Dendrophyllia indica Pillai, 1986, p. 192.

\section{Diagnosis}

Colonial, bright yellow coloured colony when alive with short, almost round corallites. The tentacles are arranged on the inner wall of the corallite and are transparent with yellowish tentacle tips. Lateral lines start from each corallite and is interconnected by the lateral lines on the coenosteum (Fig. 3a). Colonies are found on hard substratum where direct sun light hits. Some colonies are found submerged by sand, leaving less exposed corallites. This species inhabits in high water current influenced areas. No co-occurrence with any zooxanthellate scleractinians was observed. Ascidians and some gastropods were found inhabiting the area with this species. Examined colony has a total height of $21 \mathrm{~mm}$ with a greater diameter of $30 \mathrm{~mm}$. It is a juvenile, with club-shaped corallum, having 8 corallites.
Corallites are very small, projecting, and measured up to $4 \mathrm{~mm}$ in the largest form. Corallites have only 3 septal cycles. Calices 6 to $11 \mathrm{~mm}$ in diameter and up to $9 \mathrm{~mm}$ deep (Fig. 3b-d). Septal and other characters are similar to the paratypic specimen reported by Pillai (1969).

\section{Distribution}

This species has been reported previously from Tuticorin, east coast of India (Pillai, 1969) and from Kadiyapptanam, southernmost west coast of India (Pillai and Jasmine, 1995). Present account extends its distribution to midwest coast of India. This species is the most abundant azooxanthellate scleractinian of the southwest coast of India.

Order SCLERACTINIA Bourne, 1900

Suborder DENDROPHYLLIINA Vaughan \& Wells, 1943

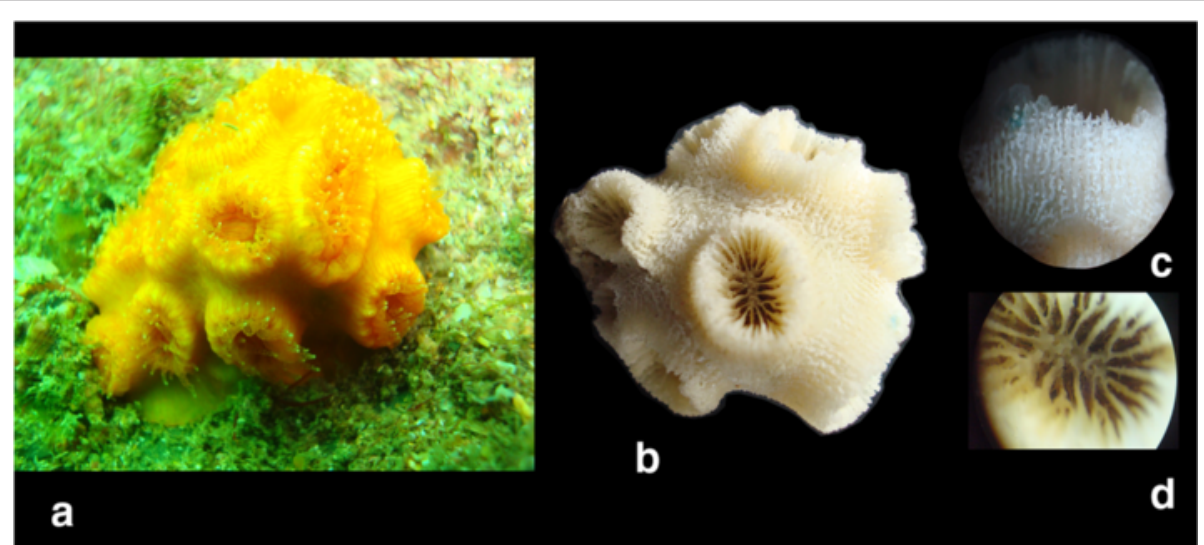

Fig. 3 Azooxanthellate scleratinian corals recorded from Goa, mid-west coast of India. a In situ specimen of Dendrophyllia indica Pillai, 1969. b Bleached corallite of Dendrophyllia indica. c-d Stereoscopic images of the septa of Dendrophyllia indica Pillai, 1969 


\author{
Family CARYOPHYLLIDAE Gray \\ Subfamily CARYOPHYLLIINAE Gray \\ Paracyathus Milne Edwards \& Haime, 1848 \\ Paracyathus profundus Duncan, 1889 \\ (Fig. 4a-d) \\ Paracyathus profundus Duncan, 1889, p. 4, p. 1, Figs. \\ 4-6, \\ Paracyathus profundus Pillai, 1986, p. 183
}

\section{Diagnosis}

This is a juvenile, solitary corallite with whitish outer corallum and dark brownish calice, tansparent tentacles and a projected oral disc at the centre of calice. Tentacles are narrower towards the tip and end with blunted ends. Surface of tentacles are with white granuleswhich are thick at the tip. Corallum also has a bended pedicel, and its surface is reddish white in colour. The base or holdfast is broad and firmly attached on the substrate (Fig. 4a). Total height measured $8 \mathrm{~mm}$ and found attached on an encrusting sponge. All septa are exerted and slightly arched. Septal edges are granular. Coralllum is almost cylindrical and its diameter measured $7.5 \mathrm{~mm}$. Three cycles of septa with bi or tri lobed pali. Costa extend to the base of corallite. Calicular fossae chocolate brown in colour. Corallum is cylindrical and almost uniform in thickness from the base to top Pali are prominent with bi or tri lobed (Fig. 4b-d).

\section{Distribution}

This species has its previous report from Mergui Archipelago, Myanmar, Australia (Cairns, 1998) and Palk Bay and Gulf of Mannar (Pillai, 1986) and Kadiyapptinam, southwest coast of India (Pillai and Jasmine, 1995). The present study extends the distribution range of this species to the middle west coast of India.

\section{Discussion}

The scientific knowledge of scleractinian corals has considerably increased. Out of the 245 scleractinian corals reported so far from Indian waters, only 34 species are azooxanthellates (Turner et al. 2001). The seas and the deep shelf regions adjacent to India have had few surveys and limited reports only are available on the occurrence of azooxanthellate corals [Pillai and Scheer (1976) from Nicobar; Pillai (1983, 1986, 1988); Venkataraman et al. (2003) from Gulf of Kachchh, Gulf of Mannar, Lakshadweep, and Andaman and Nicobar Islands]. Gulf of Mannar recorded more number of species (20 species) followed by Andaman and Nicobar region (13 species). Lakshadweep and Gulf of Kachchh has only 4 species each (Table 1). Recently Venkataraman (2007) reported the distribution of 8 azooxanthellate corals from off Chennai, South east coast of India. Present study confirms the presence of three azooxanthellate corals off Goa, mid-west coast of India. Detailed further studies along the coast would unveil the presence of more number of species. The major human impact on azooxanthellate scleractinian corals of the study area is due to trawl fishing activities in the continental shelf and deep-sea regions of the coast. It is probable that many deep-water coral habitats and associated fauna are being trawled before they are fully studied and their species diversity assessed.

\section{Conclusion}

The distribution of three azooxanthellate scleractinian corals has reported for the first time from the rocky reefs of mid-west Indian coast. Despite their biodiversity, the littoral and the deep shelf regions adjacent to India have not surveyed properly for azooxanthellate corals. Detailed further studies along the coast would unveil the

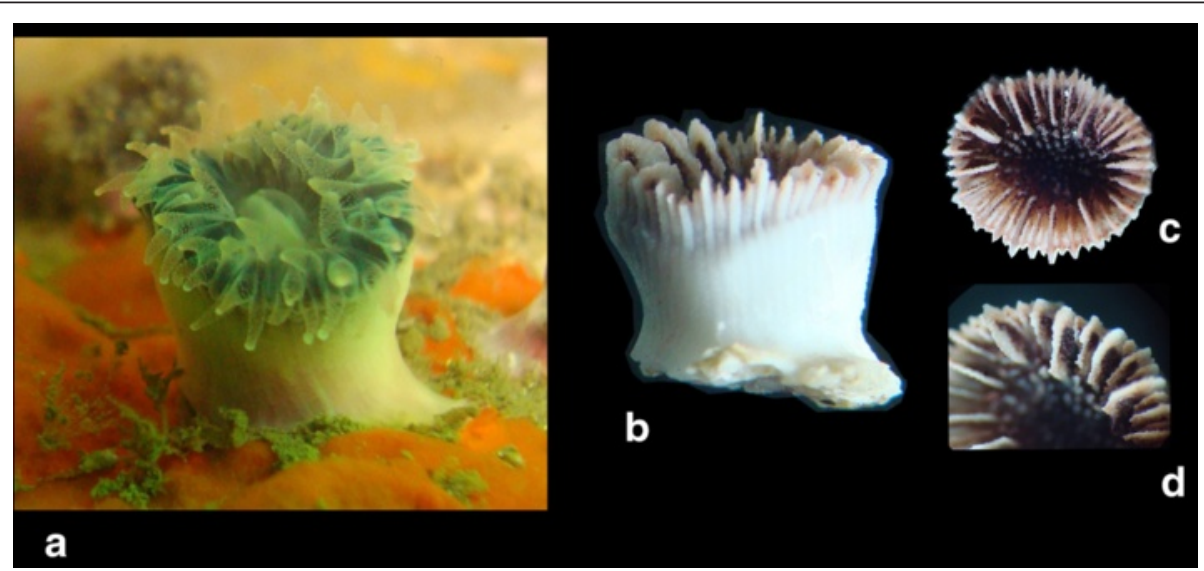

Fig. 4 Azooxanthellate scleratinian corals recorded from Goa, mid-west coast of India. a In situ specimen of Paracyathus profundus Duncan, 1889. b Bleached corallite of Paracyathus profundus. c-d Stereoscopic images of the septa of Paracyathus profundus 
presence of more number of species. In-situ morphological characters of the species will help to identify the specimen on the spot and may reduce excess sampling.

\section{Acknowledgement}

The authors record their sincere thanks to the Ministry of Environment Forests and Climate Change, Govt. of India, New Delhi for funding this study and Dr. Stephen D. Cairns, National Museum of Natural History, Smithsonian Institution, USA for confirming the species identity. Diving assistance by Mr. Venkat Charloo, Barracuda Diving, Goa, India is also kindly acknowledged.

\section{Authors' contribution}

$\mathrm{RC}$ encountered the specimens, recorded the in-situ morphological characters of the specimens, RC and SL identified the specimens and finalized the manuscripts. Both authors read and approved the final manuscript.

\section{Authors' information}

RC: M.Sc., Zoology, Ph.D., Aquatic Biology \& Fisheries, Scientist at IERSE, Nagercoil, India. SL: M.Sc. Marine Biology, Ph.D., Aquatic Biology \& Fisheries, D.Sc. Marine Biology, Director, IERSE, Nagercoil, India.

\section{Competing interests}

The authors declare that they have no competing interests.

Received: 4 August 2016 Accepted: 4 August 2016

\section{Published online: 01 September 2016}

\section{References}

Alcock A. Newly recorded corals from the Indian Seas. J Asiat Soc Bengal. 1893; 62:130-49.

Alcock A. An account of the Madreporaria collected by the Ritak Ubduab Narube Syrvet Sguo 'Investigator'. Investigator Reports. Calcutta: Indian Museum; 1898. p. $1-29$

Cairns SD. Scleractinia of the Temperatue North Pacific, Smithson. Contrib Zool. 1994:557:1-164

Cairns SD. Azooxanthellate Scleractinia (Cnidaria: Anthozoa) of Western Australia. Rec West Aust Mus. 1998;18:361-417.

Cairns SD. The azooxanthellate Scleractinia (Coelenterata: Anthozoa) of Australia. Rec Aust Mus. 2004:56:259-329.

Cairns SD, Kitahara MV. An illustrated key to the genera and subgenera of the recent azooxanthellate Scleractinia (Cnidaria, Anthozoa), with an attached glossary. Zookeys. 2012;227:1-47.

Cairns SD, Stanley GD. Ahermatypic coral banks: living and fossil counterparts. Proc Fourth Int Coral Reef Symp Held Manila (1981). 1982;1:611-8.

Dinesen ZD. Regional variation in shade-dwelling coral assemblages of the Great Barrier Reef Province. Mar Ecol Prog Ser. 1982;7:117-23.

Dinesen ZD. Shade-dwelling corals of the Great Barrier Reef. Mar Ecol Prog Ser. 1983;10:173-85.

Pillai CSG. Report on a new species of Dendrophyllia (Scleractinia, Dendrophylliidae) from the Gulf of Mannar. J Mar Biol Ass India. 1969:9(2):407-9.

Pillai CSG. Structure and generic diversity of recent Scleractinia of India. J Mar Bio Ass India. 1983;25:78-90.

Pillai CSG. Recent corals of the southeast coast of India. In: Recent advances in Marine Biology. New Delhi: Today and Tomorrow Printers and Publishers; 1986. p. 107-201.

Pillai CSG. Scleractinian corals from the Gulf of Kutch. J Mar Biol Ass India. 1988;30:54-74

Pillai CSG, Sheer G. Report on the stony corals from the Maldive Archipelago. Zoologica. 1976;126:1-83.

Pillai CSG, Jasmine S. Scleractinian corals of the Erstwhile Travancore coast (Southwest of India). J Mar Biol Ass India. 1995;37:109-25.

Turner JR, Vousden D, Klaus R, Satyanarayana Ch, Fenner D, Venkataraman K, Rajan PT and Subba Rao NV. Report of Phase I: Remote sensing and Rapid Site Assessment Survey, April 2001. Coral Reef ecosystems of the Andaman Islands. GOI/UNDP GEF, Director of Zool. Sur. India, Kolkata, India, 2001. p. 1-76.

Venkataraman K. Coral reefs in India. Chennai: National Biodiversity Authority; 2006. p. 1-18.
Venkataraman K. Azooxanthellate hard corals (Scleractinia) from India. In: George RY. Cairns, SD. editors. Conservation and adaptive management of seamount and deep-sea coral ecosystems. Rosenstiel School of Marine and Atmospheric Science. Miami: University of Miami; 2007. p. 209-14.

Venkataraman K, Satyanarayana C, Alfred JRB, Wolstenholme J. Hand book on Hard Corals of India. India: Publ. Director, Zoo. Surv; 2003. p. 1-266.

\section{Submit your next manuscript to BioMed Central and we will help you at every step:}

- We accept pre-submission inquiries

- Our selector tool helps you to find the most relevant journal

- We provide round the clock customer support

- Convenient online submission

- Thorough peer review

- Inclusion in PubMed and all major indexing services

- Maximum visibility for your research

Submit your manuscript at www.biomedcentral.com/submit 